\title{
THE LIFE AND WORK OF THE STUDENT OF THE RIGA POLYTECHNIC INSTITUTE, PSALMIST JAAN JÜRJENS (1866-1915)
}

SERGEJS COJA*

Riga Anniņmuiža Secondary School

\begin{abstract}
Summary. Jaan Jürjens was an Estonian of Russian Orthodox faith. He graduated from the Riga Orthodox Theological Seminary in 1888 and from St. Petersburg Orthodox Theological Academy in 1902. From 1907 to 1910, he studied at the Department of Agriculture of Riga Polytechnic Institute. During the late 19th and early 20th centuries, he served the Russian Orthodox Church and fellow humans as churchwarden, elementary school teacher and professor of Orthodox Theological Seminary. Jaan Jürjens is an author of several published books and scientific papers.
\end{abstract}

Keywords: Riga Orthodox Theological Seminary, Riga Polytechnic Institute, Estonian psalmist, Jaan Jürjens.

\section{Studies, spiritual and pedagogical work}

At the end of the 19th century and at the beginning of the 20th century, students of different nationalities, including Estonians, studied at the Riga Polytechnic Institute. One of them was Jaan Jürjens (in Russian Иван Юрьенс (Ivan Juriens; 1866-1915), who spent much of his life in Riga. He studied and worked there.

Jaan Jürjens was born in Tõstamaa parish located in Pärnu county, which was the municipality of Vidzeme on 7 February ${ }^{1} 1866$. He was born in a poor family of an Orthodox farmer Antonijs Jürjens and his Lutheran wife Rino Jürjens in Selu Manor (at present - Seliste) in Viggakse village, Mardu house. Jürjens' home is located near Seli-Tõstamaa congregation's

\footnotetext{
1 In article, the dates are listed after the Gregorian calendar or in a new style.
}

\footnotetext{
* Corresponding author.

E-mail: coja@baltinet.lv
} 
Great Orthodox Church of Saint Vasily, in whose metric book an entry was made on the birth and baptisation of J. Jürjens on 15 February [1].

The information about Jaan Jürjens' childhood is miserly. Apparently, he attended the local school of Orthodox Church Congregation, after which, around 1878, as the best pupil of this school entered the Riga Spiritual School, and later studied at the Riga Orthodox Theological Seminary. This educational path at that time was the only one that gave him the opportunity to get a good education. Dedication and excellent work ability helped J. Jürjens to achieve his life goals.

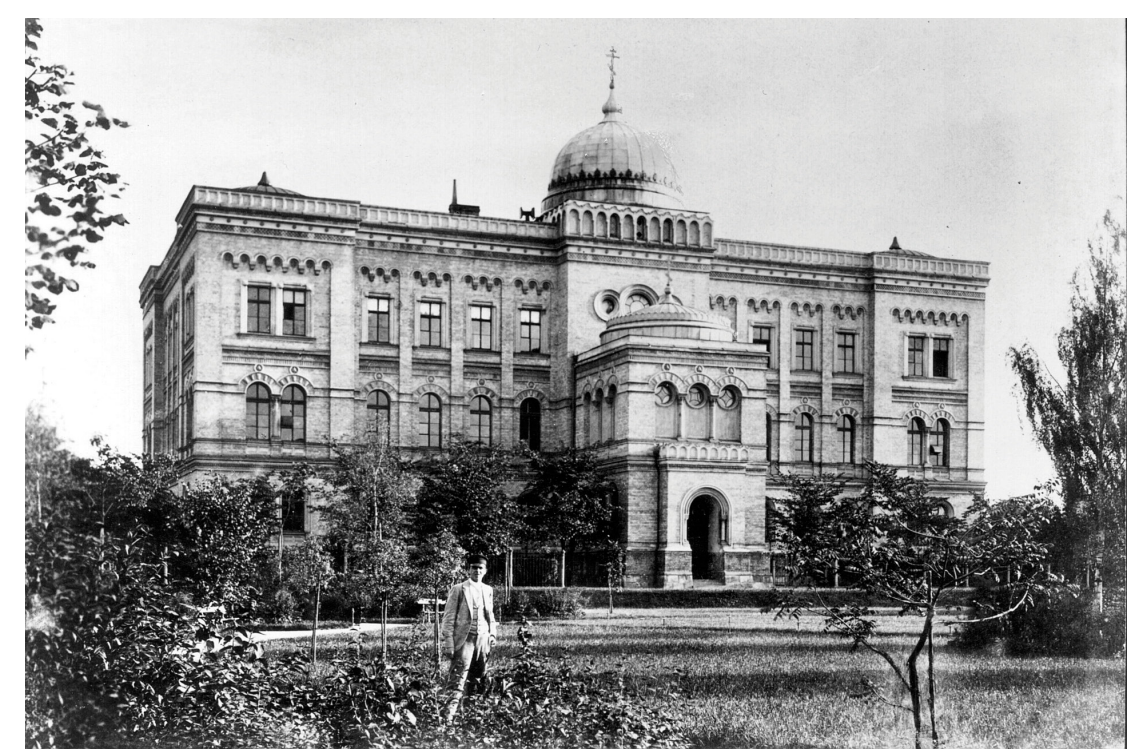

Figure 1. Riga Orthodox Theological Seminary building, nowadays - Riga Stradin̋̌s University building at 9 Kronvalda Boulevard [2].

In 1888, J. Jürjens was the first student to graduate from the Riga Orthodox Theological Seminary [3]. This educational institution has been functioning since 1851, and it accepted children who had good results in the four-year Spiritual School. The students of the seminary received secondary education as well. The studies in the seminary lasted six years. During the first four years, the curriculum was equated with the course of the proto-gymnasium (gymnasium with a facilitated program), but in the last two years emphasis was placed on theological subjects [4].

After the completion of the seminary, J. Jürjens became the psalmist in Vendauas (at present - Vinna) Christ's Birth Orthodox Church. In early 1889, he was transferred to the Orthodox Church of Saint John and the Holy Trinity, located in the Eriko Manor in Saaremaa Island. From 1890 to 1892, J. Jürjens was a psalmist in the church of Saint Nicholas 
in Kuressaare, and at the congregation school of the Orthodox church he taught Russian language and singing. Later, until 1894, he served as a psalmist in the Orthodox Church of Saint John the Baptist in Viljandi, where he also worked as a teacher. For his dedicated and successful work as a teacher the School Council expressed gratitude to him, which was published on 1 December 1895 by the journal «Рижские Епархиальные Ведомости» («Magazine for Riga's eparchy») in August 1895 [5]. J. Jürjens was appointed a teacher of religious studies to the Kreenholm Elementary School (two grades) situated near the Kreenholm Factory in Narva city [6]. He worked at this school until 12 August 1897 [7].

Despite the tiny amounts of money that psaltery and teachers received at that time, J. Jürjens managed to collect the necessary funds and continue his studies. In 1897, he entered the Saint Petersburg Orthodox Theological Academy from the beginning as a free listener. In 1902, J. Jürjens graduated from the Academy and obtained a degree of Candidate in Theology with the right to reflect the Master's degree in Theology without a new oral test [8; 9].

J. Jürjens profoundly knew the Bible, knew classical languages, Sanskrit, Estonian and Russian literature, which gave him good prospects in the future. However, he decided to return to Riga, where he had studied, and began to work as a teacher of the Estonian language at the Riga Orthodox Theological Seminary for a relatively low salary [10]. In his obituary we can read: «.. they ${ }^{2}$ always noted the success of their students with the highest marks; were most tolerant to failure [11].» It should be noted that there were other Estonians working in the seminary, too, for example Peeter Mihkelson (1842-1914) [12; 13]. They worked at an educational institution, the Riga Orthodox Theological Seminary, which provided good education, which had good grounds at the beginning of the 20th century [14].

In 1907, J. Jürjens joined the Department of Agriculture of the Riga Polytechnic Institute. It is likely that he wanted to obtain a diploma of agronomist in order to work in agriculture. At that time, most of Estonians were farmers, including J. Jürjens' parents. Certified engineers had a prospect of earning more than teachers. Unfortunately, he did not receive an RPI diploma because in January 1910 J. Jürjens did not pay the tuition fee and left the Institute [15].

In 1908, for his contribution for the good of society, J. Jürjens was awarded with the Order of Saint Stanislaus. At the same time, he ranked as a college assessor in the ranking of the Russian Empire [16].

Estonian Jaan Jürjens was not married and lived alone. During the last years of his life, he had been ill with tuberculosis, which shortened his life [17]. J. Jürjens died on 9 February 1915. On the day of his death, the deceased was brought to the premises of the Riga Orthodox Theological

2 J. Jürjens and his colleague P. Mihkelson. 
Seminary at Puškina Street, Riga (at present - 9 Kronvalda Boulevard) and was placed in the Assembly Hall. The Panihid was carried out by the Archbishop of Riga and Jelgava cities John (Ivans Smirnovs; И. Смирнов; 1844-1919; he governed the Riga Eparchy from 1910 to 1917). The burial took place on 11 February in the Pokrova Cemetery in Riga. The funeral liturgy was led by the Rector of the Seminar, the Chief Priest Aleksey Ljebedev (Алексеи Лебедев; 1856-1918). The periodicals and magazines of that time published articles about J. Jürjens' funeral saying that the seminarians loved their teacher and their eyes were full of tears at his burial. A colleague of the deceased, Chief Priest V. Pliss (В. Плисс; 18621927), read the lines from I. Njikitin's poem «Вырыта заступом яма глубокая» («Deep pit dug with shovel») and described the work of the deceased warmly, emphasizing that J. Jürjens' was striving to give benefit his favourite seminary and Orthodox Estonians [18]. To this day, J. Jürjens grave has not survived in the Pokrova cemetery in Riga [19].

\section{Articles and books written by Jaan Jürjens}

At the end of his lifetime, J. Jürjens has written several articles and books, mainly devoted to the Baltic history, published in the Russian language. In 1904, J. Jürjens' work «Древнейшая Ливонская хроника» («The Oldest Livonian Chronicle») [20], dedicated to the Livonian Chronicle

\section{ЛИВОНСКАЯ ХРОНИЯА.}

Ив. ЮPbEHCЪ.
Figure 2. Cover of J. Jürjens' book «Древнейшая Ливонская хроника» («The Oldest Livonian Chronicle») (1904) [20].

of Henry, written in the beginning of the 13th century, depicting events in the territories of Latvia and Estonia in the late 12th and early 13th centuries [21]. J. Jürjens defended the thesis that Priest Indrikis (Henry) who is mentioned in the chronicle, and who is considered him to be the author of the text by most of the scientists, cannot be called the author [22]. J. Jürjens held that the arguments of historians were based only on guesswork. The location of Priest Indrikis' (Henry) congregation far from Riga shows his low social status and the fact that he had not had 
sufficient education to write a chronicle of such a level. The author of the text, without a doubt, is a priest, but certainly of a higher level than a congregation priest. In addition, J. Jürjens wrote that apparently the author of the chronicle was a German, since the author of the chronicle presents himself as the German at least twice in the chronicle [23]. Some of his arguments are controversial and do not prove anything. For example, his statement that a priest residing far from Riga congregation could not have a good level of education.

In 1910, J. Jürjens' brochure «Прибалтийский край под русской властью: к 200 летн. юбилею присоединения Прибалтийского края к Русской державе: 4 июля 1710-4 июля 1910 г.» («The Baltic States under the influence and government of Russia: In commemoration of the 200th anniversary of the accession of the Baltic States to Russia: 4 July 1710 July 4, 1910.») was published [25]. This work by J. Jürjens was translated and published in Latvian [25]. Translators signed as J. and K. Perhaps one of the translators is an attorney, newspaper and journal collaborator, Jānis Pelūde (1873-1911), whose nickname was «J». The pseudonym «K» was used by poet Kârlis Eliass (1899-1985), who was a pupil of about 10 to 11 years of age when the work was being translated [26], so there are doubts, whether he could be one of the translators. Although the local Latvian press acknowledged the translation as «amateurish» [27], librarians who have been managing the printing of catalogues and processing information, had not indicated real translators. The publication of the brochure was adapted for the 200th anniversary of the conquest and annexation of the territory of Estonia and Vidzeme to the Russian Empire. The official character of the work can be seen at the beginning. J. Jürjens defended the thesis that the Baltic lands belonged to Russia before the Germans appeared there, and Tsar Peter I only returned to the beginning of the 18th century. The work also contains a detailed historical review of the 12th-13th century events. Further attention is focused on the year 1710 and the 1840s, associated with the spread of Orthodoxy and the conversion of local people to Orthodoxy [28]. In this brochure, the Russian Empire and the Russian people were praised during the time when the Baltic provinces were subject to Russification. The work has no scientific value, because it served only for political propaganda of Russian authorities of that time. Obviously, J. Jürjens had been commissioned to write this manuscript, from which he could not refuse, because he was dependent on Propaganda of Russian Politics of that time as a teacher of the Riga Orthodox Theological Seminary. Unfortunately, this brochure does not convey his own attitude to these events. In the event of a criticism, the Tsarist censorship would not have allowed it to be printed.

In 1912, J. Jürjens published the book «Эстская грамматика: со статьями для чтения и построчнымъ словарем» («Estonian grammar 
with articles for reading and a dictionary of the subtitles») [29]. This is a short Estonian textbook having an introduction and explanations in Russian language. It contains both Estonian grammar and materials for reading and a small Estonian-Russian dictionary. At that time, there was a deficit of this type of publications, therefore the author prepared the book.

The last work of J. Jürjens «Вопрос о ливонской дани» («The Issue of the Livonian Order Duties») was published in 1913 in Warsaw. It was dedicated to the question about the taxes paid by the Livonian lands to the Russian rulers. The urgency of this topic, as emphasized by the author, was related to raising the issue of Russian rights to the Baltic lands, which was one of the reasons for the beginning of the Livonian War. The work tells about several contracts that were concluded at different times between the Livonian rulers and Russia, in which were mentioned the taxes in favour of the latter. It was incredibly difficult to judge real amount of duties. The Russians relied on this right to the old duty, which were paid by a part of the local people in favour of the Russian princes before the Germans arrived in the Baltic States. About Ioannes IV (Иоанн IV; Иван Грозный; 1530-1584) claiming these duties, J. Jürjens wrote that at that time the right to ask duty from someone was based solely on the law of the strongest [30]. The big Russia was stronger, so Livonia had to pay.

Estonian Jaan Jürjens lived for 49 years. Despite poor financial conditions and poor health, he managed to get a good education, to serve his people as an Orthodox psalmist, a teacher of public schools and the Riga Orthodox Theological Seminary Pedagogue, as well as to write several articles and books.

\section{LIST OF SOURCES AND LITERATURE}

[1] Estonian arhives in Tartu (EAA) 1973. 1. 478. Sv. Vasīlija Lielā draudzes Seli-Testamaa pareizticīgās baznīcas metrisku grāmata par 1865.-1868. g.

[2] Rīgas Pareizticīgo Garīgā semināra ēka Puškina ielā 9 (patlaban - Kronvalda bulv. 9) 20. gadsimta sākumā. Foto no D. Trubeckoja personīgā arhīva.

[3] Razrjadnyj spisok vospitannikov Rizhskoj duhovnoj seminarii, sostavlennyj v pedagogicheskom sobranii pravlenija 20-21 ijunja 1888 g. posle byvshih ispytanij. Rizhskie Eparhialnye Vedomosti, 1888, No. 13-14, s. 393.

[4] Vičs, A. Latviešu skolu vēsture. Piektā grāmata. Laikmets no 1905.-1915. Rīga, R.L.B. Derīgu grāmatu nodaḷas apgāds, 1940, 328.-329. lpp.

[5] Ot uchilishhnogo soveta. Rizhskie Eparhialnye Vedomosti, 1895, Nr 1, s. 11.

[6] Latvijas Valsts vēstures arhīvs (LVVA) 4754. f., 2. apr., 147. l., 992. lp.; 167.l., 1487.-1488. lpp. Rīgas eparhijas klēru raksti par 1894. gadu. 
[7] EAA 260.1.467; J. Jurjena personāllieta, 1895.-1897. g.

[8] Ivan Antonovich Jurjens. Rizhskie Eparhialnye Vedomosti, 1915, No. 4, s.126.

[9] Prepodavatel rizhskoj duhovnoj seminarii Ivan Antonovich Jurjens. Rizhskij Vestnik, 1915, No. 22, s. 1.

[10] LVVA, 7416. f., 1. apr., 7. 1., 2., 26., 60.lp.

[11] Ivan Antonovich Jurjens. Rizhskie Eparhialnye Vedomosti, 1915, No. 4, s. 124.

[12] Nekrolog. Pohorony prepodavatelja P. M. Mihkelsona. Rizhskie Eparhialnye Vedomosti, 1914, No. 21, S. 629-631.

[13] Vidjakina, S. A., Kovalchuk, S. N. (sost.). Pokrovskoe kladbishhe. Slava I zabvenie.-Sbornik statej. Riga: Multicentrs, 2004, s. 71.

[14] Vičs, A. Latviešu skolu vēsture. Piektā grāmata. Laikmets no 1905.-1915. Rīga, R.L.B. Derīgu grāmatu nodaḷas apgāds, 1940, 320.-322. lpp.

[15] LVVA 7175. f., 1. apr., 1908. l., 166. lp. RPI studentu registrs.

[16] Eparhialnye izvestija. Vysochajshie nagrady. Rizhskie Eparhialnye Vedomosti, 1908, No. 10, s. 376.

[17] LVVA, 7416. f., 1. apr., 1. l., 1.-2.lp. , Rīgas Pareizticīgo Garīgā semināra valdes sēdes protokoli.

[18] Gorodskoj dnevnik. Pohorony I. A. Jurjensa. Rizhskij Vestnik, 1915, No. 24, s. 3.

[19] Vidjakina S. A., Kovalchuk S. N. (sost.). Pokrovskoe kladbishhe. Slava I zabvenie.-Sbornik statej. Riga: Multicentrs, 2004, s. 95.

[20] Jurjens I. A. Drevnejshaja Livonskaja hronika. Otdelnyj ottisk iz Zapiski imperatorskogo russkogo arheologicheskogo obshhestva. Tom V, vyp. 2. Sanktpeterburg, 1904, 17 s.

[21] Coja, S. Henriha / Indrika chronicon Livoniae autora identitātes problēma Krievijas historiogrāfijā. Latvijas Vēstures Institūta Žurnāls, 2011, No. 3, 72. lpp.

[22] Coja, S. Die Frage der Herkunft des Chronisten Henrich von Lettland in der russischen Historiografie. In: Forschungen zur baltischen Geschichte. Band 9. Tartu: Akadeemiline ajalooselts, 2014, S. 19-20.

[23] Jurjens I. A. Drevnejshaja Livonskaja hronika. Otdelnyj ottisk iz Zapiski imperatorskogo russkogo arheologicheskogo obshhestva.Tom V, vyp. 2. Sanktpeterburg, 1904, 2., 7., 11., 12., 14. str.

[24] Jurjens I. A. Pribaltijskij kraj pod russkoj vlastju. K 200-letn. jubileju prisoedinenija Pribaltijskogo kraja k russkoj derzhave (4 ijulja 1710-4 ijulja1910 goda. Riga: tipografija G. Gemel i Ko, 1910, 24 s.

[25] Jurjens J. Baltija zem Krievijas iespaida un valdības. Baltijas pie Krievijas pievienošanas 200-gadu jubilejai par pieminu. Rīga: Rīgas Pētera-Pāvila brālības izdevums, 1910, 24 lpp.

[26] Latviešu rakstniecība biogrāfijās. Rīga: Zinātne, 2003, 697., 698. lpp.

[27] Grāmatu plaukts. Dzimtenes Vēstnesis, 1910. No. 157, 3. lpp.

[28] Jurjens J. Baltija zem Krievijas iespaida un valdības. Baltijas pie Krievijas pievienošanas 200-gadu jubilejai par piemiṇu. Rīga: Rīgas Pētera-Pāvila brālības izdevums, 1910, 5., 20., 22.-23. lpp. 
[29] Jurjens I. A. Estskaja grammatika: so statjami dlja chtenija i postrochnym slovarem. Riga: Tip. T. Vilks i E. Shkinkis, 1912, 96 s.

[30] Jurjens I. A. Vopros o Livonskoj dani. Varshava:Tip. Varshavskogo uchebnogo okruga, 1913, s. 1.-6, 52.-53., 39., 41., 57. lpp.

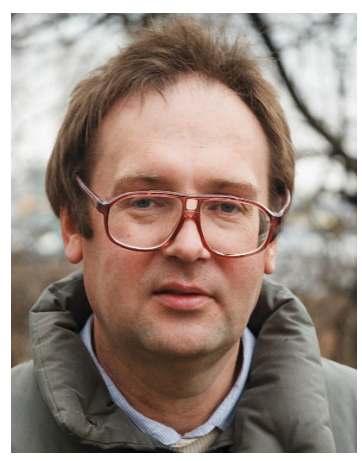

SERGEJS COJA, Mg. hist., is a teacher at the Riga Anniņmuiža Secondary School (since 2013). His main academic interests are the history of pedagogy, and history of national minorities in Latvia.

Address: 50 Tapešu Street, Flat 10, Riga, LV-1083, Latvia

Phone: +37129105468

E-mail: coja@baltinet.lv

Sergejs Coja

\section{Rīgas Politehniskā institūta studenta, psalmotāja Jāna Jurjena dzives un darba gaitas (1866-1915)}

Pareizticīgais igaunis Jāns Jurjens 1888. gadā absolvēja Rīgas Pareizticīgo Garīgo semināru un 1902. gadā - Sanktpēterburgas Garīgo akadēmiju.Vinšs studēja Rīgas Politehniskā institūta (RPI) Lauksaimniecības nodaḷā (1907-1910). 19. gadsimta beigās un 20. gadsimta sākumā J. Jurjens kalpoja pareizticīgajai baznīcai un ticīgajiem kā psalmotājs, tautskolu skolotājs un Rīgas Pareizticīgo Garīgā semināra pedagogs. Vinšs ir vairāku grāmatu un zinātnisko rakstu autors.

Atslēgas vārdi: Rīgas Pareizticīgo Garīgais seminārs, Rīgas Politehniskais institūts, igauṇu psalmotājs, Jāns Jurjens.

Сергей Цоя

\section{Жизненный путь и трудовая деятельность студента Рижского политехнического института, псаломщика Яана Юрьенса (1866-1915)}

Иван (Яан) Антонович Юрьенс - православный эстонец, обучался в 1907-1910 годах на Сельскохозяйственном отделении Рижского политехнического института. В 1888 году он окончил Рижскую православную духовную семинарию, а в 1902 году Санкт-Петербургскую духовную академию. В конце XIX - начале XX служил Православной церкви и простым людям, учителем народных школ, преподавателем духовной семинарии. И. А. Юрьенс являлся автором нескольких книг и научных статей.

Ключевые слова: Рижская православная духовная семинария, Рижский политехнический институт, Иван Юрьенс. 